Original Research Paper

\title{
Anti-Proliferative Activity of Zerumbone Against Tumour Cell Lines
}

\author{
${ }^{1,2}$ Adel Sharaf Al-Zubairi \\ ${ }^{I}$ Department of Laboratory Medicine, Faculty of Applied Medical Sciences, \\ Albaha University, Al-Baha, Kingdom of Saudi Arabia \\ ${ }^{2}$ Department of Biochemistry and Molecular Biology, \\ Faculty of Medicine and Health Sciences, Sana'a University, Sana'a Yemen
}

Article history

Received: 11-12-2017

Revised: 11-04-2018

Accepted: 24-04-2018

Tell: +967734825031

$+966540994415$

Email: adelalzubairi@hotmail.com

\begin{abstract}
Zerumbone (ZER) is a cytotoxic phytochemical component extracted from the tropical herbal plant, Zingiber Zerumbet smith. It has been identified as an active anticancer compound. This study was aimed to evaluate in vitro the anti-proliferative activity of this bioactive compound, zerumbone, on seven cancer cell lines namely: CEMss (T4lymphoplastoid), Chinese Hamster Ovary (CHO), 3T3 (mouse fibroblast), WEHI-3 (murine monomyelocytic leukemia), HeLa (Human cervical cancer), MCF-7 (human breast cancer) and MDA-MB-231 (human mammary cancer-estrogen negative). The antiproliferative activity of ZER was evaluated using 3-[4,5-dimethylthizol-2-yl]-2,5diphenyltetrazolium bromide (MTT) assay, together with the commercially available anticancer drug Cisplatin as a control drug. The most sensitive cells to ZER were found to be WEHI-3B, 3T3 and Hela cell lines with an $\mathrm{IC}_{50}$ of 5,6 and $6.4 \mu \mathrm{g} \mathrm{mL}^{-1}$, respectively, followed by CEMss cell lines with an $\mathrm{IC}_{50}$ of $12 \mu \mathrm{g} \mathrm{mL} \mathrm{m}^{-1}$. This indicates the possible potential use of ZER for treatment of hematological cancers in addition to the cervical cancer. Meanwhile, ZER was found to be less toxic to the normal cell lines $\mathrm{CHO}$.
\end{abstract}

Keywords: Zerumbone, Cell Lines, Antiproliferative Activity, MTT

\section{Introduction}

Asian traditional medicine has introduced the medicinal herbs for treatment of various ailments including malignant cancers. The most frequently used medicinal herbal preparations in Asian traditional medicine were formulated from the Zingiberaceae family. It has been used for treatment of sores, swelling and loss of appetite. The boiled rhizome's juice has been used as medicines for treatment of worm infestations in children. The rhizomes have been known in Asian traditional medicine for treatment of many diseases and in particular for treatment of many gastrointestinal tract conditions (Jang et al., 2004; Prakash et al., 2011). Rhizomes extracts have been found to exhibit antispasmodic and anticonvulsant (Yob et al., 2011), anti-inflammatory (Sulaiman et al., 2010; Zakaria et al., 2010), anticancer (Rashid and Pihie, 2005; Bustamam et al., 2008; Abdul et al., 2008a), antibacterial (Abdul et al., 2008b; Kader et al., 2011), antipyretic (Somchit et al., 2005), antidiabetic (Tzeng et al., 2013), antioxidant (Habsah et al., 2000), antitumour (Wahab et al., 2008) and antiulcer (Al-Amin et al., 2012) effects, while the young shoots have been used as condiments. The main active constituents of the volatile oils of the rhizomes were found to contain zerumbone, humuline and camphene (Jang et al., 2005).

The sesquiterpene compound, Zerumbone is isolated from the wild ginger, Zingiber zerumbet Smith plant, which is locally known in Malaysia as 'lempoyang' and belongs to the Zingiberaceae family. Zerumbone has been known for its activity in vitro and in vivo against many diseases. It has been shown to be actively suppress free radical generation and skin tumor initiation and promotion and inhibit inducible nitric oxide synthase, cyclooxygenase 2 expression and TNF- $\alpha$ release in activated leukocytes (Chen et al., 2011), while suppress the formation of colonic tumour marker in rats and 
ameliorate the proliferation of human colonic adenocarcinoma cell lines and induces apoptosis in human colorectal cancer cell lines (Murakami et al., 2002; 2004). In addition, Zerumbone has been reported to modulate osteoclastogenesis induced by RANKL and breast cancer (Sung et al., 2009) as well as carcinogenesis process suppression in mouse colon and lung (Kim et al., 2009). Our previous in vivo studies have shown zerumbone to have an activity against Cervical Intraepithelial Neoplasia (CIN) in mice (Bustamam et al., 2008).

Medicinal plants represent a substantial source for the development of new anticancer drugs, new drug precursors and new chemical entities despite the advantages of the synthetic ones (Newman et al., 2000; Dikshit et al., 2004). Medicinal plants have a significant contribution to the field of drug discovery as many modern drugs gain their origin from traditional medicine of different cultures. The aim of this work was to evaluate the in vitro antiproliferative activity of ZER against different haematological and solid tumours cell lines namely; CEMss, CHO, 3T3, WEHI-3B, HeLa, MCF-7 and MDA-MB-231.

\section{Materials and Methods}

\section{Zerumbone (ZER)}

ZER was extracted in the laboratory of cancer research MAKNA-UPM, University Putra Malaysia, from the rhizomes parts of the Zingiber zerumbet plant (Abdul et al., 2008a). The rhizomes of the plant have been obtained locally from the wet market in Kuala Lumpur, Malaysia. Methanol extraction and Column Chromatography (CC) method has been used to isolate, extract and purify ZER. To determine its molecular weight and purity, the isolated and purified crystals were subjected to High Performance Liquid Chromatography (HPLC) and Liquid Chromatography Mass Spectrometry (LCMS) followed by 13C NMR and 1H NMR analysis to ascertain its molecular structure. ZER stock solution has been prepared in absolute ethanol immediately before use.

\section{Cell Cultures and Maintenance}

Solid tumours cell lines used in this study included; HeLa (Human cervical cancer), MCF-7 (human breast cancer), MDA-MB-231 (human mammary cancer estrogen negative) and 3T3 (mouse fibroblast) were obtained from ATTC, while hematological tumours cell lines included; WEHI-3B (murine monomyelocytic leukemia cell lines) were obtained from ATTC and CEMss (T4-lymphoplastoid) cell lines were obtained from NIH (AIDS Research and Reference Reagent Program, Division of AIDS, NIAID, NIH: USA). In addition to the normal cells, $\mathrm{CHO}$ (Chinese hamster ovary cell line) was obtained from ECACC. All the cell lines were cultivated in RPMI 1640 supplemented with $10 \%$ fetal calf serum, $1 \%$ penicillin-streptomycin and $1 \%$ amphotericin $B$. The culture flasks were incubated in a humidified incubator supplied with $5 \%$ $\mathrm{CO}_{2}$ and set at $37^{\circ} \mathrm{C}$ temperature. They were frequently checked under inverted microscope (Micros, Austria). On 80\% confluency, the media was removed and the cells were washed 3 times with $7 \mathrm{~mL}$ of PBS (Phosphate Buffer Saline). Trypsin has been used for the detachment of adherent after $5 \mathrm{~min}$ incubation. The flasks then were gently tapped to detach the cells and 10 milliliters of RPMI 1640 with $10 \%$ FCS was added and the content of the flasks were resuspended to allow the cells to disperse. Then $6 \mathrm{~mL}$ of cell suspension was transferred into a $75 \mathrm{~cm}^{3}$ flask. Finally, ten milliliters of RPMI 1640 with 10\% FCS was added and incubated in $\mathrm{CO}_{2}$ incubator at $37^{\circ} \mathrm{C}$. The cells were frequently checked under an inverted microscope for confluency and viability.

\section{Cytotoxicity Assay (MTT)}

DMSO (Sigma Aldrich, Germany) has been used to solubilize ZER crystals and diluted in RPMI 1640 media to give final concentrations of 100 and $120 \mu \mathrm{g} \mathrm{mL}^{-1}$, while a stock solution of 60 and $100 \mu \mathrm{g} \mathrm{mL}^{-1}$ cisplatin were prepared from $1 \mathrm{mg} \mathrm{mL} L^{-1}$ stock solution as a control for the test system. Confluent cultures were washed 3 times with PBS, detached trypsin and were incubated for $5 \mathrm{~min}$ in the $\mathrm{CO}_{2}$ incubator. To the detached cells, $10 \mathrm{~mL}$ of RPMI with $5 \%$ FCS was added into the flask and counted using a hemocytometer. One hundred microliters of cell suspension were plated in each well of 96 well plates at concentration of $1 \times 10^{5}$ cells $\mathrm{mL}^{-1}$ and incubated for $24 \mathrm{~h}$ after which they were treated with different concentrations of ZER and cisplatin. The cells were incubated in $\mathrm{CO}_{2}$ incubator at $37^{\circ} \mathrm{C}$ for 3 days $(72 \mathrm{~h})$. The MTT (3-(4,5-dimethylthiazol-2-yl)-2,5-diphenyl tetrazolium bromide) (Amresco) assay method used according to that described by Mossman (1983). Five milligrams/mL MTT (Micro culture Tetrazolium) has been prepared, from which $20 \mu \mathrm{L}$ was added into each well. The aluminum foil covered plates were then incubated in dark at $37^{\circ} \mathrm{C}\left(5 \% \mathrm{CO}_{2}\right)$ for 4 hours to allow the active live cells to convert water soluble yellow MTT solution into water insoluble purple formazan. Four hours later, the media containing MTT solution was removed and the remaining purple formazan crystals were dissolved in $100 \mu \mathrm{L}$ DMSO and measured using ELISA plate reader at $450 \mathrm{~nm}$ (TECAN, SunriseTM, Männedorf, Switzerland). The median leathal concentration $\left(\mathrm{IC}_{50}\right)$ value (Concentration at which $50 \%$ of the cells are viable and another $50 \%$ cells killed) was calculated from the dose-response curve $(\%$ cell viability versus concentration of ZER or cisplatin). 


\section{Results and Discussion}

Seven cell lines have been exposed to increasing concentrations of ZER, four cell lines belong to solid tumours namely HeLa, MCF-7, MDA-MB-231 and 3T3 and two cell lines were of hematological origin WEHI-3B and CEMss. The seventh cell line was non-tumour derived, normal cell lines, CHO cell lines. Cell viability was determined by the MTT assay. In vitro cytotoxic activity $\left(\mathrm{IC}_{50} \mu \mathrm{g} / \mathrm{mL}\right)$ of ZER and Cisplatin tested against different tumour cell lines incubated for $72 \mathrm{~h}$ is shown in Table 1 .
Table 1: In vitro cytotoxic activity $\left(\mathrm{IC}_{50} \mu \mathrm{g} / \mathrm{mL}\right)$ of ZER and Cisplatin tested against different tumour cell lines incubated for $72 \mathrm{~h}$

\begin{tabular}{lcc}
\hline Cell lines & ${\text { ZER } \mathrm{IC}_{50}(\mu \mathrm{g} / \mathrm{mL})}$ & Cisplatin $\mathrm{IC}_{50}(\mu \mathrm{g} / \mathrm{mL})$ \\
\hline 3T3 & 6.0 & 4.6 \\
Hela & 6.4 & 2.8 \\
MCF-7 & 23.0 & 6.1 \\
MDA-MB 231 & 24.3 & 13.0 \\
CEMss & 12.0 & 8.5 \\
WEHI-3B & 5.0 & 3.5 \\
CHO & 25.4 & 5.0 \\
\hline
\end{tabular}

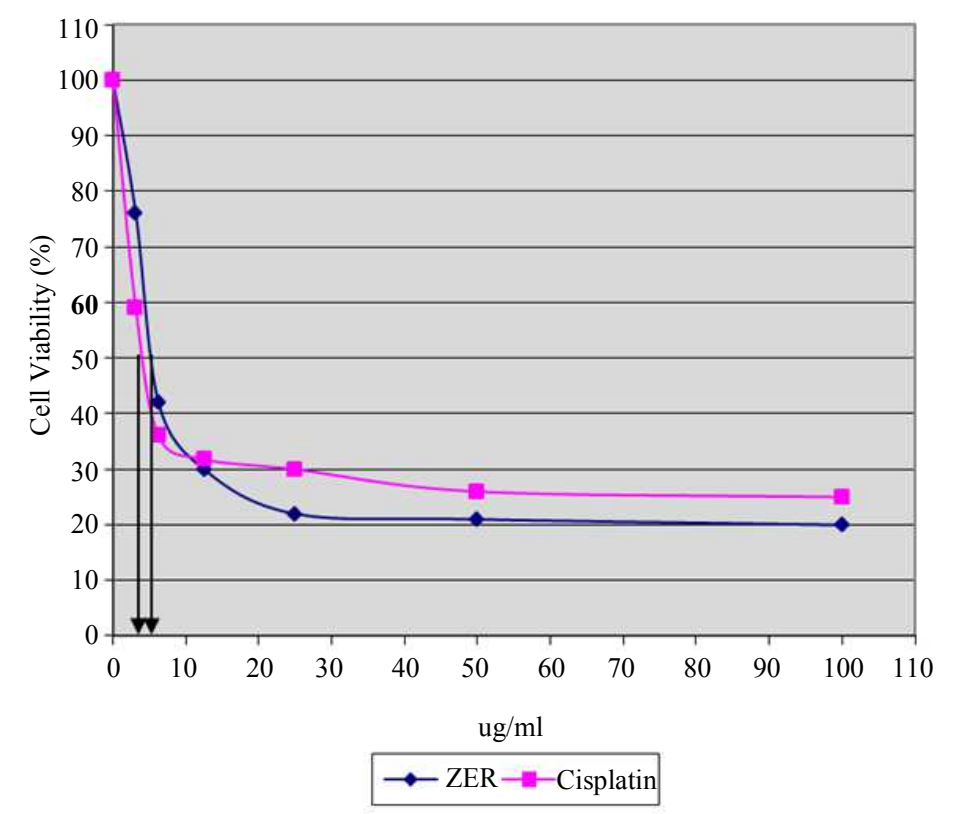

Fig. 1: Antiproliferative activity of ZER and Csiplatin on $3 \mathrm{~T} 3$ cell lines

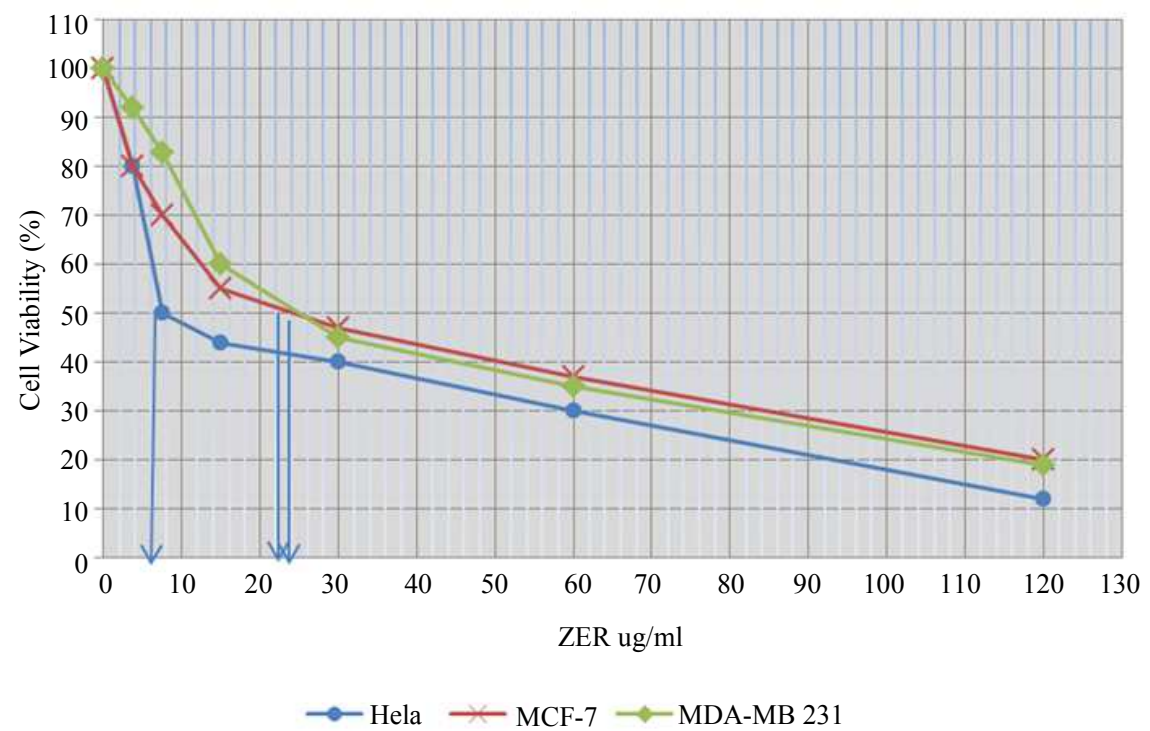

Fig. 2: Antiproliferative activity of ZER against Hela, MCF-7, MDA-MB 231 cell lines 


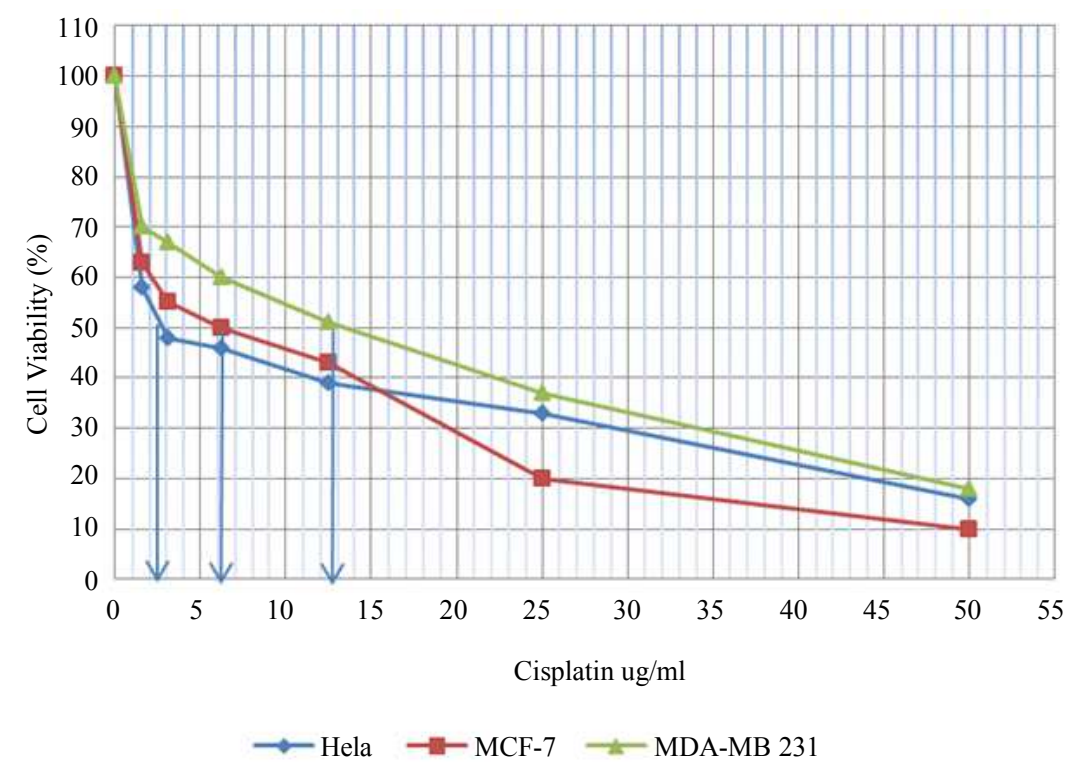

Fig. 3: Antiproliferative activity of Cisplatin against Hela, MCF-7, MDA-MB 231 cell lines

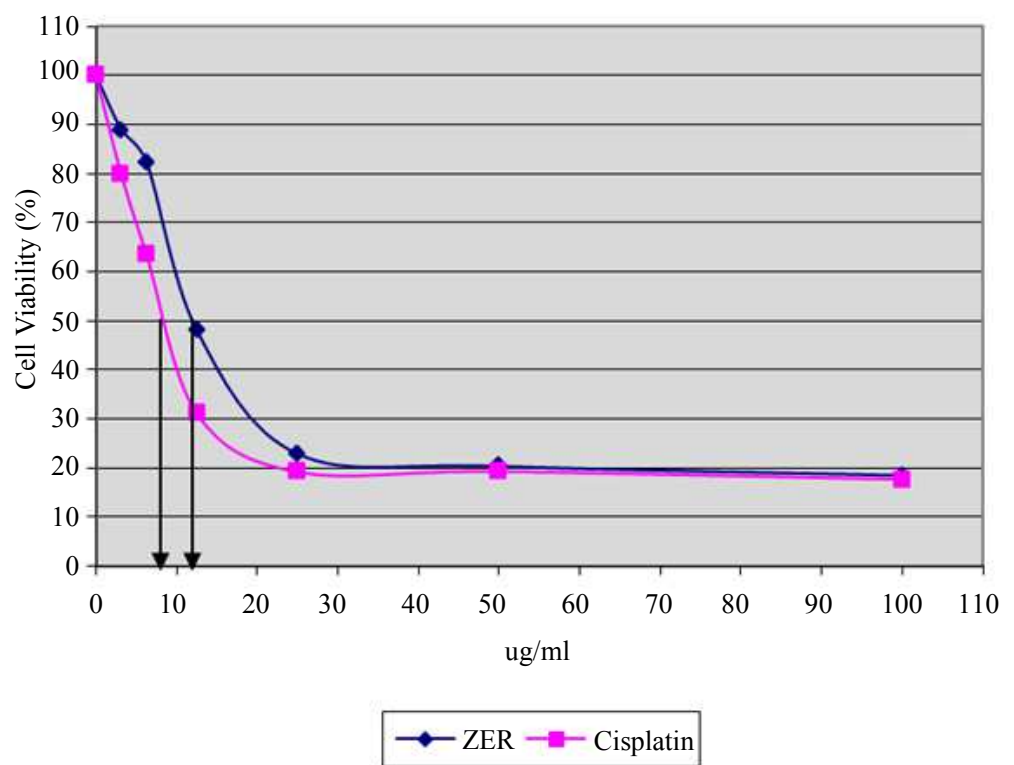

Fig. 4: Antiproliferative activity of ZER and Csiplatin on CEMss cell lines

This study indicated that the higher concentration of ZER, the lesser percentage of cell viability in all tested cell lines (Fig. 1 to 6). This suggests an increase in the toxic effects of ZER with the increase in the concentration. The smaller the $\mathrm{IC}_{50}$ of a compound the more toxic compound it was. ZER showed different antiproliferative activities towards the seven cell lines under investigation. Results present the $\mathrm{IC}_{50}$ values of ZER (the required concentration to reduce cell viability by $50 \%$ after $72 \mathrm{~h}$ of incubation compared to control wells) (Table 1). $\mathrm{IC}_{50}$ values were determined by plotting dose response curves for the ZER in the range (1-120 $\mu \mathrm{g}$ $\left.\mathrm{mL}^{-1}\right)$ and Cisplatin in the range of $\left(2.5-100 \mu \mathrm{g} \mathrm{mL}^{-1}\right)$. The $\mathrm{IC}_{50}$ values of the reference drug Cisplatin were ranged from 2.8-8.5 $\mu \mathrm{g} \mathrm{mL}^{-1}$ against all tested cell lines. ZER exhibited effective antiprolifrative activity towards WEHI-3B, 3T3 and Hela cell lines with $\mathrm{IC}_{50}$ values of 5, 6 and $6.4 \mu \mathrm{g} \mathrm{mL}^{-1}$ respectively. These three cell lines were shown to be the most sensitive to Cisplatin as well, with $\mathrm{IC}_{50}$ values of $\left(3.5,4.6\right.$ and $2.8 \mu \mathrm{g} \mathrm{mL} \mathrm{m}^{-1}$, respectively). The antiproliferative activity of ZER displayed in this study against human cervical cancer cells (Hela) was in 
agreement with the finding of Alwi et al. (2007) while IC50 value of ZER against human breast cancer cells $\mathrm{MCF}-7$ was found to be higher. In accordance with the American Cancer Institute (NCI) protocol, which recommends considering the $\mathrm{IC}_{50}$ values $\leq 30 \mu \mathrm{g} \mathrm{mL}^{-1}$ to be potent cytotoxic crude extracts of plant origin, while for pure substances the $\mathrm{IC}_{50}$ values $\leq 4 \mu \mathrm{g} \mathrm{mL}$ considered to be effective anticancer agent (Geran et al.,
1972), ZER with $\mathrm{IC}_{50}$ values approaching the $4 \mu \mathrm{g} \mathrm{mL}^{-1}$ could be considered a potent cytotoxic pure substance. The antiproliferative effects of ZER against MCF-7 and MDA-MB-231 tumour cell lines were found to be less effective with $\mathrm{IC}_{50}$ values of 23 and $24.3 \mu \mathrm{g} \mathrm{mL}$, respectively. Meanwhile ZER cytotoxic activity against $\mathrm{CHO}$ non-tumour cell lines was found to be the lowest cytotoxic with $\mathrm{IC}_{50}$ value of $25.4 \mu \mathrm{g} \mathrm{mL}^{-1}$.

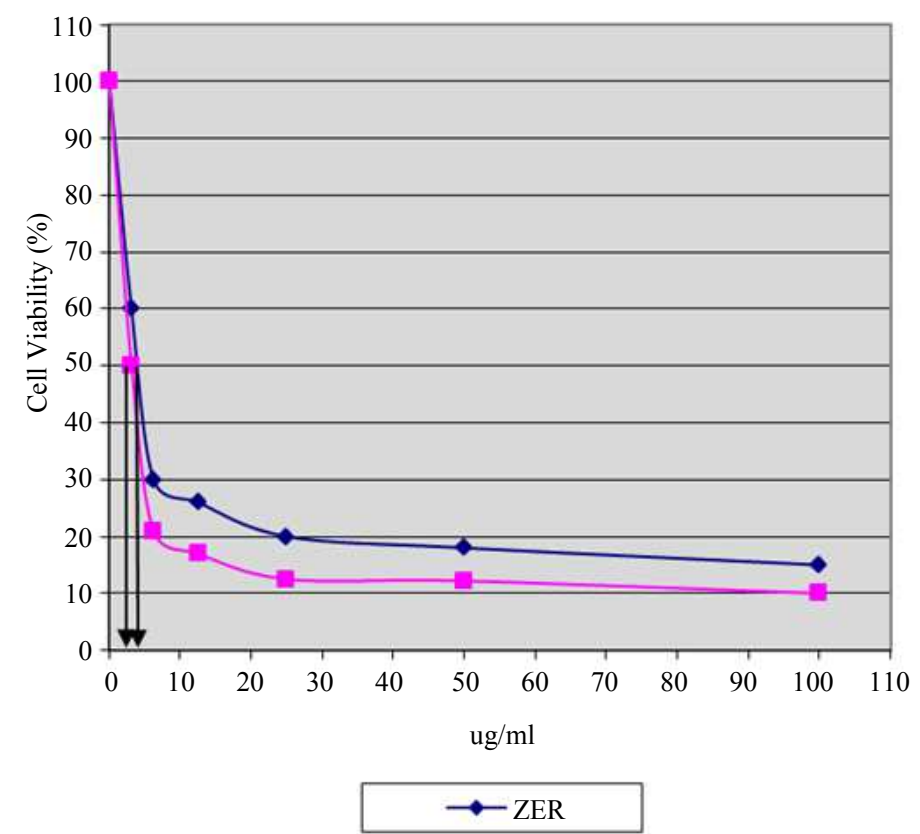

Fig. 5: Antiproliferative activity of ZER and Csiplatin on WEHI-3B cell lines

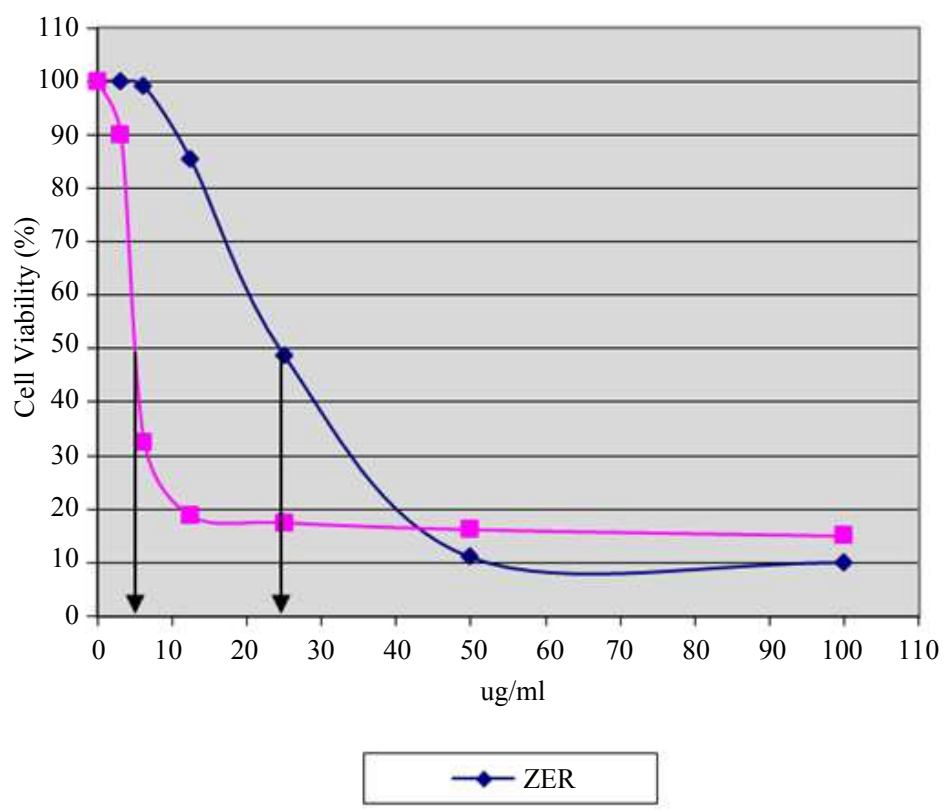

Fig. 6: Antiproliferative activity of ZER and Csiplatin on CHO cell lines 
ZER is naturally occurring substance with potent anticancer cytotoxic effects and being extracted from edible plant gains added advantage due to low toxicity over the synthetic anticancer compounds. It has been suggested previously that ZER could act as effective as anticancer agent with a substantial chemotherapeutic potential against cervical cancer cells (Abdul et al., 2008a) and against several tumour cell lines (Sadhu et al., 2007). In the meantime the effects on non-malignant cell was found to be less compared to the malignant cells and this is in agreement with the earlier findings of Hoffmann el al. (2002) who observed that appropriate dose of ZER inhibited the proliferation of cancer cells but have no effect on the normal cells (Alwi et al., 2007; Sadhu et al., 2007).

\section{Conclusion}

ZER was most cytotoxic against WEHI-3B, 3 T3 and Hela with promising concentrations to be used as an anticancer drug. In addition, CEMss cell line was found to be sensitive to ZER while other cell lines were shown to be sensitive to ZER with lesser degree, MCF-7 and MDA-MB 231. The non-tumour cell lines $\mathrm{CHO}$ cell lines were shown to be less sensitive to ZER. We can conclude that the effects of zerumbone seem to be cytoselective towards tumour cells.

\section{Acknowledgment}

The author would like to thank Albaha University for their support to publish this work (Project number (78/1438) and would like to appreciate the cooperation of MAKNA-UPM Cancer research Lab., Institute of Biosciences, University of Putra Malaysia for performing the cytotoxicity assay.

\section{Conflicts of Interest}

The authors declare no conflict of interest.

\section{References}

Abdul, A.B., A.S. Al-Zubairi, N.D. Devi, S.I. Wahab and Z.N. Zain et al., 2008a. Anticancer activity of natural compound (zerumbone) extracted from Zingiber zerumbet in human HeLa cervical cancer cells. Int. J. Pharmacol., 4: 160-168. DOI: 10.3923/ijp.2008.160.168

Abdul, A.B., S.I. Wahab, A.S. Al-Zubairi, M.M. ElHassan and M.M. Syam, 2008b. Anticancer and antimicrobial activities of zerumbone from the rhizomes of Zingiber zerumbut. Int. J. Pharmacol., 4: 301-304. DOI: 10.3923/ijp.2008.301.304

Al-Amin, M., G.N.N. Sultana and C.F. Hossain, 2012. Antiulcer principle from Zingiber montanum. J. Ethnopharmacol., 141: 57-60.

DOI: $10.1016 /$ j.jep.2012.01.046
Alwi, S.S.S., M. Nallappan and A.H.L. Pihie, 2007. Zerumbone exerts antiproliferative activity via apoptosis on HepG2 cells. Malaysian J. Bioch. Mol. Biol., 15: 19-23.

Bustamam, A., S. Ibrahim, N. Devi, M.N. Hakim and A.S. Al-Zubairi et al., 2008. The establishment and use of an in vivo animal model for Cervical Intraepithelial Neoplasi. Int. J. Cancer Res., 4: 61-70. DOI: 10.3923/ijcr.2008.61.70

Chen, B.Y., D.P. Lin, C.Y. Wu, M.C. Teng and C.Y. Sun et al., 2011. Dietary zerumbone prevents mouse cornea from UVB-induced photokeratitis through inhibition of NF- $\kappa \mathrm{B}$, iNOS and TNF- $\alpha$ expression and reduction of MDA accumulation. Mol. Vis., 6: 854-863. PMID: 21527993

Dikshit, A., S.K. Shahi, K.P. Pandey, M. Patra and A.C. Shukla, 2004. Aromatic plants a source of natural chemotherapeutants. Nat. Acad. Sci. Lett., 27: 145-164.

Geran, R.I., N.H. Greenberg, M.M. Macdonald, A.M. Schumacher and B.J. Abbott, 1972. Protocols for screening chemical agents and natural products against animal tumors and other biological systems. J. Can. Chemother. Rep., 3(2): 1-103.

Habsah, M., M. Amran, M.M. Mackeen N.H. Lajis and H. Kikuzaki et al., 2000. Screening of Zingiberaceae extracts for antimicrobial and antioxidant activities. J. Ethnopharmacol., 72: 403-410. DOI: $10.1016 / \mathrm{S} 0378-8741(00) 00223-3$

Hoffman, A., L.M. Spetner and M. Burke, 2002. Redocregulated mechanism may account for zerumbone's ability to suppress cancer-cell proliferation. Carcinogenesis, 23: 1961-1962.

DOI: $10.1093 /$ carcin/23.11.1961

Jang, D.S., A.R. Han, G. Park, G.J. Jhon and E.K. Seo, 2004. Flavonoids and aromatic compounds from the rhizomes of Zingiber zerumbet. Arch. Pharm. Res., 27: 386-389. DOI: 10.1007/BF02980078

Jang, D.S., H.Y. Min, M.S. Kim, A.R. Han and T. Windono et al., 2005. Humulene derivatives from Zingiber zerumbet with the inhibitory effects on lipopolysaccharide-induced nitric oxide production. Chem. Pharm. Bull., 53: 829-831. DOI: $10.1248 / \mathrm{cpb} .53 .829$

Kader, G., F. Nikkon, M.A. Rashid and T. Yeasmin, 2011. Antimicrobial activities of the rhizome extract of Zingiber zerumbet Linn, Asian Pac. J. Trop. Biomed., 1: 409-412. DOI: 10.1016/S2221-1691(11)60090-7

Kim, M., S. Miyamoto, Y. Yasui, T. Oyama and A. Murakami et al., 2009. Zerumbone, a tropical ginger sesquiterpene, inhibits colon and lung carcinogenesis in mice. Int. J. Cancer, 124: 264-271. DOI: $10.1002 /$ ijc. 23923 
Mossman, T., 1983. Rapid colorimetric assay for cellular growth and survival: Application to proliferation and cytotoxicity assays. J. Immunol. Meth., 65: 5563. DOI: 10.1016/0022-1759(83)90303-4

Murakami, A., D. Takahashi, T. Kinoshita, K. Koshimizu and H.W. Kim et al., 2002. Zerumbone, Southeast Asian ginger sesqiuterpene, markedly suppresses free radical generation, pro-inflammatory protein production and cancer cell proliferation accompanied by apoptosis: The $\alpha, \beta$-unsaturated carbonyl group is a prerequisite. Carcinogenesis, 23: 795-802. DOI: 10.1093/carcin/23.5.795

Murakami, A., M. Miyamoto and H. Ohigashi, 2004. Zerumbone, an anti-inflammatory phytochemical, induces expression of proinflammatory cytokine genes in human colon adenocarcinoma cell lines. Biofactors, 21: 95-101.

DOI: $10.1002 /$ biof.552210118

Newman, D.J., G.M. Cragg and K.M. Snader, 2000. The influence of natural products upon drug discovery. Nat. Prod. Rep., 17: 215-234.

DOI: $10.1039 / \mathrm{a} 902202 \mathrm{c}$

Prakash, R.O., R.K. Kumar, A. Rabinarayan and M.S. Kumar, 2011. Pharmacognostical and phytochemical studies of Zingiber zerumbet (L.) Smith rhizome. Int. J. Res. Ayurv Pharm, 2: 698-703.

Rashid, R.A. and A.H.L. Pihie, 2005. The antiproliferative effects of Zingiber zerumbet extracts and fractions on the growth of human breast carcinoma cell lines. Malaysian J. Pharmaceut. Sci., 31: 45-52.

Sadhu, S.K., A. Khatun, T. Ohtsuki and M. Ishibashi, 2007. First isolation of sesquiterpenes and flavonoids from Zingiber spectabile and identification of zerumbone as the major cell growth inhibitory component. Nat. Prod. Res., 21: 1242-1247. DOI: $10.1080 / 14786410701371421$
Somchit, M.N., M.H. Shukriyah, A.A. Bustamam and A. Zuraini, 2005. Anti-pyretic and analgesic activity of Zingiber zerumbet, Int. J. Pharmacol., 1: 277-280. DOI: 10.3923/ijp.2005.277.280

Sulaiman, M.R., E.K. Perimal, M.N. Akhtar, A.S. Mohamad and M.H. Khalid et al., 2010. Antiinflammatory effect of zerumbone on acute and chronic inflammation models in mice. Fitoterapia, 81: 855-858. DOI: 10.1016/j.fitote.2010.05.009

Sung, B., A. Murakami, B.O. Oyajobi and B.B. Aggarwal, 2009. Zerumbone abolishes RANKLinduced NF-B activation, inhibits osteoclastogenesis and suppresses human breast cancer induced bone loss in athymic nude mice. Cancer Res., 69: 1477-1484. DOI: 10.1158/0008-5472.CAN-08-3249

Tzeng, T.F., S.S. Liou, C.J. Chang and I.M. Liu, 2013. The ethanol extract of Zingiber zerumbet attenuates streptozotocin-induced diabetic nephropathy in rats. Evid. Based Complement. Alternat. Med., 2013: 340645-340645. DOI: 10.1155/2013/340645

Wahab, S.I.A., A.B. Abdul, H.C. Yeel, A.S. Alzubain and M.M. Elhassan et al., 2008. Anti-tumor activities of analogues derived from the bioactive compound of Zingiber zerumbet. Int. J. Can. Res., 4: 154-159. DOI: 10.3923/ijcr.2008.154.159

Yob, N.J., S.M. Jofrry, M.M.R. Affandi, L.K. Teh and M.Z. Salleh et al., 2011. Zingiber zerumbet(L.) Smith: A review of its ethnomedicinal, chemical and pharmacological uses. Evid. Based Complement. Alternat. Med, 2011: 543216-543216. DOI: $10.1155 / 2011 / 543216$

Zakaria, Z.A., A.S. Mohamad, C.T. Chear, Y.Y. Wong and D.A. Israf et al., 2010. Antiinflammatory and antinociceptive activities of Zingiber zerumbet methanol extract in experimental model systems. Med. Prin. Practic., 19: 287-294. DOI: $10.1159 / 000312715$ 